\title{
Grazer density and songbird counts in a restored conservation area
}

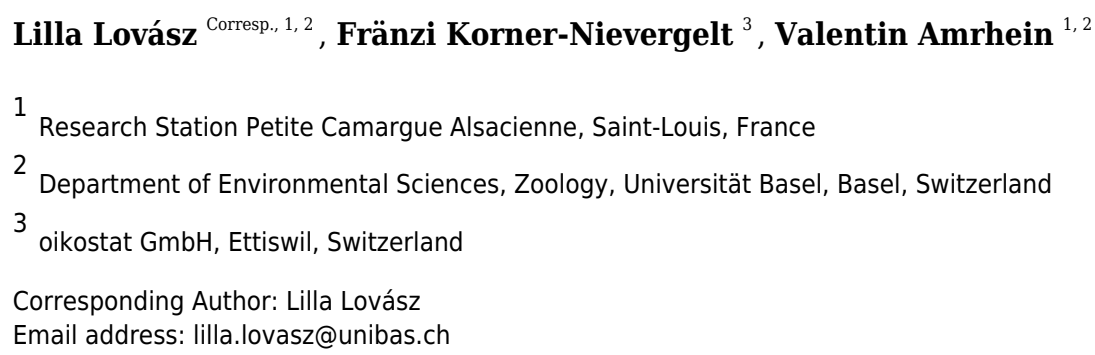

Grazing by large herbivores is increasingly used as a management tool in European nature reserves. The aim is usually to support an open but heterogeneous habitat and its corresponding plant and animal communities. Previous studies showed that birds may profit from grazing but that the effect varies among bird species. Such studies often compared bird counts among grazed areas with different stocking rates of herbivores. Here, we investigated how space use of Konik horses and Highland cattle is related to bird counts in a recently restored conservation area with a year-round natural grazing management. We equipped five horses and five cattle with GPS collars and correlated the density of their GPS positions on the grazed area with the density of bird observations from winter through the breeding season. We found that in the songbirds of our study site, both the overall density of bird individuals and the number of species increased with increasing density of GPS positions of grazers. Correlations of bird density with horse density were similar to correlations with cattle density. Of the eight most common songbird species observed in our study area, the Eurasian Skylark and the Common Starling had the clearest positive correlations with grazer density, while the Blackbird showed a negative correlation. Skylarks and Starlings in our study area thus seem to profit from year-round natural grazing by a mixed group of horses and cattle. 
1

2 Grazer density and songbird counts in a restored 3 conservation area

4

5

6 Lilla Lovász ${ }^{1,2}$, Fränzi Korner-Nievergelt ${ }^{3}$, Valentin Amrhein ${ }^{1,2}$

7

$8{ }^{1}$ Department of Environmental Sciences, Zoology, University of Basel, Basel, Switzerland

$9 \quad 2$ Research Station Petite Camargue Alsacienne, Saint-Louis, France

$10{ }^{3}$ oikostat $\mathrm{GmbH}$, Ettiswil, Switzerland

11

12 Corresponding Author:

13 Lilla Lovász ${ }^{1}$

14 Research Station Petite Camargue Alsacienne, Rue de la Pisciculture, Saint Louis 68300, France

15 Email address: lilla.lovasz@unibas.ch 
16

17

18

19

20

21

22

23

24

25

26

27

28

29

30

31

32

33

34

35

36

37

38

39

40

41

42

43

44

45

46

47

48

49

50

51

52

53

54

\section{Abstract}

Grazing by large herbivores is increasingly used as a management tool in European nature reserves. The aim is usually to support an open but heterogeneous habitat and its corresponding plant and animal communities. Previous studies showed that birds may profit from grazing but that the effect varies among bird species. Such studies often compared bird counts among grazed areas with different stocking rates of herbivores. Here, we investigated how space use of Konik horses and Highland cattle is related to bird counts in a recently restored conservation area with a year-round natural grazing management. We equipped five horses and five cattle with GPS collars and correlated the density of their GPS positions on the grazed area with the density of bird observations from winter through the breeding season. We found that in the songbirds of our study site, both the overall density of bird individuals and the number of species increased with increasing density of GPS positions of grazers. Correlations of bird density with horse density were similar to correlations with cattle density. Of the eight most common songbird species observed in our study area, the Eurasian Skylark and the Common Starling had the clearest positive correlations with grazer density, while the Blackbird showed a negative correlation. Skylarks and Starlings in our study area thus seem to profit from year-round natural grazing by a mixed group of horses and cattle.

\section{Introduction}

Bird communities in open landscapes are often positively influenced by ungulate grazing, due to the heterogenous, structure-rich environment created by the grazers (Roth 1976; van Klink et al. 2016; VanWieren 1995; Vera 2000). Although a negative influence of grazing on birds is sometimes reported, for example due to intense grazing on farmland (Dross et al. 2018), lowintensity grazing is generally agreed to be beneficial for most bird species, especially those of higher conservation concern (Nikolov 2010). Therefore, grazing by one or more species of large herbivores is increasingly used as a management tool in European nature conversation areas (Henning et al. 2017; Loucougaray et al. 2004; Rosenthal et al. 2012).

The extent to which bird species react to grazing likely depends on how much they rely on the particular niches affected by grazing (Milchunas et al. 1988). For example, shortened vegetation may provide suitable nesting habitat and higher food availability and accessibility for some bird species (Leal et al. 2019; Toepfer \& Stubbe 2001), while others may be impeded by the effect of trampling (Sharps et al. 2017). The Eurasian Skylark Alauda arvensis is one example of a species that was shown to require open and structurally diverse habitat mosaics with relatively short vegetation to maximize the number of nesting attempts (Toepfer \& Stubbe 2001; Wilson et al. 1997). While the Skylark seems to generally profit from grazing, trampling was reported to be a main cause of nest loss on meadows grazed by livestock at high densities (Pavel 2004). 
55

56

57

58

59

60

61

62

63

64

65

66

67

68

69

70

71

72

73

74

75

76

77

78

79

80

81

82

83

84

85

86

87

88

89

90

91

92

93

94

Studies so far mainly compared how the impact of grazing on breeding bird communities differs between enclosures with different stocking rates of large herbivores (Baldi et al. 2005; Dross et al. 2018). For example, Batary et al. (2007) found that grassland birds were more abundant on extensively grazed areas compared to intensively grazed areas, while this was not the case in non-grassland birds.

However, the habitat use by grazers within an enclosure is usually not homogenous (Gander et al. 2003; King \& Gurnell 2005). For understanding the influence of space use patterns of grazers on birds within a given grazed area, it may help to obtain position data of individual grazers. One example of such a study is Köhler et al. (2016), who investigated space use of horses in relation to a bird assemblage in a German nature reserve by using a GPS collar on one horse. The authors found that the density of bird observations, especially in the Skylark, was higher where the density of horse GPS positions was higher.

Here, we studied how counts of songbirds from winter through the breeding season are related to the space use of a mixed assemblage of five Konik horses and five Highland cattle in a French nature reserve that was recently ecologically restored. In this study area, the applied management approach is natural grazing, a low intensity $(<0.5$ animal units per hectare) yearround mixed grazing regime with the aim of substituting extinct wild herbivores such as the wild horse (Equus ferus) or the aurochs (Bos primigenius) with domestic breeds kept in semi-wild conditions, i.e., without systematic winter feeding and with minimal human intervention (Linnell et al. 2015; Vermeulen 2015). We investigated how the overall counts of songbird individuals and of the number of songbird species correlated with the density of grazer GPS positions, and how the correlations varied among songbird species and in horses versus cattle.

\section{Materials \& Methods}

Study site

Our study site (Fig. 1) is located on the Rhine island of the nature reserve Petite Camargue Alsacienne in France, north of Basel, Switzerland. About 100 ha of the island has been part of an ecosystem restoration project since 2014. During the restoration process, the former crop fields on the area have been turned into an alluvial environment. A mixed habitat of grassland scattered with bushes (hawthorn, dog rose) and gravel sites was constructed, surrounded by patches of old forests (oak, ash). Since the beginning of the restoration project, saplings of willow and poplar are increasingly growing on some parts of the area. The water of the Rhine is led through the island in small creeks, and several ground-water ponds have been created.

The study was done with permission of the national nature reserve Petite Camargue Alsacienne.

Grazer data 
95

96

97

98

99

100

101

102

103

104

105

106

107

108

109

110

111

112

113

114

115

116

117

118

119

120

121

122

123

124

125

126

127

128

129

130

131

132

133

134

Konik horses and Highland cattle were gradually introduced into a 32-ha test enclosure on the island between September 2018 and March 2019 to contribute to the maintenance of the heterogenous and open habitat. We equipped all horses $(n=5)$ and cattle $(n=5)$ with GPS collars (Followit, type Pellego) recording their positions once per hour, starting from the time of their arrival to the area. We used data starting from January 2019 when three cows and all five horses were present on the area; two additional oxen arrived in March 2019. The overall grazing pressure thus was approximately 0.3 animal per hectare. The data were downloaded through satellite processing from the interface of the GPS collar provider (Followit), therefore no contact to the animals was necessary to access the data. Since decades, GPS collars have been widely used on cattle without causing harm or disturbance (e.g., Turner et al. 2000; Ungar et al. 2005), and as recently discussed by Collins et al. (2014), GPS collars also comply with animal welfare requirements for horses.

GPS accuracy may be affected by atmospheric conditions, satellite or receiver errors (Hurn 1993), satellite geometry (Dussault et al. 2001), topography, overhead canopies, or adjacent structures (Di Orio et al. 2003; Moen et al. 1996); therefore the GPS fixes in our dataset likely had some imprecision. Our applied GPS collars did not record HDOP (horizontal dilution of precision) data and we therefore did not correct for inaccuracy of the fixes. However, since only $3.32 \%$ of all grazer positions fell outside the fenced area (those fixes were not included into the analysis), we assumed that this rate would not strongly influence our results (see also Ganskopp \& Johnson 2007). We considered the hourly GPS positions of the grazers as describing their "space use" (i.e., the density distribution of horses and cattle over the study area).

Bird data

In 2019, we made 22 bird surveys between 31 January and 24 July. Visits were carried out in favorable weather conditions, on days without rain and with little or no wind.

We surveyed bird abundance by transect walking on the grazed meadows; we did not include a 10.6-ha-area of old forests that was part of the enclosure, so that the final size of the studied area was 21.4 ha. We selected three line transects (Gregory et al. 2004; Laiolo 2005) over the meadow area, each of about $700 \mathrm{~m}$ length, so that all parts of the grazed meadow were in visual and/or auditory distance from a transect. A trained observer (L.L.) walked along the transects with a slow pace and marked the position of the observed birds on a digital map (Map Marker 2.11_1442). During each survey, all identified individuals from all bird species were recorded; this was our response variable "bird counts". Birds flying higher than $20 \mathrm{~m}$ above the ground without showing connection to the area were excluded (e.g., Skylarks that made territorial songflights at $>20 \mathrm{~m}$ elevation were counted, but raptors crossing $>20 \mathrm{~m}$ over the meadows or migrating Common Swifts Apus apus were not). Surveys were conducted in the mornings until noon, avoiding dawn hours to minimize detectability differences due to rapid changes in the birds' conspicuousness and activity (Dawson (1981). The order of visits of the three transects per morning were alternated systematically. Differences in bird detectability 
135 between transects were probably rather small, due to the similar open habitat of the surveyed

136

137

138

139

140

141

142

143

144

145

146

147

148

149

150

151

152

153

154

155

156

157

158

159

160

161

162

163

164

165

166

167

168

169

170

171

172

173

areas. To minimize the risk of double counts, we used a cut-off distance of $60 \mathrm{~m}$ to either side of the transects so that transects would not overlap but cover the entire grazed area, and followed the recommendation of Dawson \& Bull (1975): unless it is reasonably sure that the same individual is observed, observations are counted as different individuals.

Statistical analysis

For analysis, the study area was divided into $11350 \times 50 \mathrm{~m}$ grid cells using the corner points of the UTM grid. Our measure of bird density was the number of bird counts per survey per grid cell. Horse and cattle GPS positions (taken once per hour) were summed up per grid cell over the last 30 days prior to a bird survey, resulting in our measure of grazer (horse and cattle) density. We assumed that grazer space use patterns earlier than 30 days before the respective bird survey did not substantially influence space use of birds. Because we assumed detectability of bird species to be relatively homogeneous across the study area and our aim was not estimating the total number of birds present in the study area, we did not take detectability into account in our analyses (as, e.g., Buckland et al. 2001). Due to the migratory behaviour of some bird species, species composition changed over the course of the study. For the analyses, we excluded periods when a migratory bird species was not regularly present in our study site, which was from the $9^{\text {th }}$ survey session (1 $17^{\text {th }}$ April) for the Pipits; until the $7^{\text {th }}$ survey session (23rd March) for the Barn Swallow; and until the $12^{\text {th }}$ survey session ( $4^{\text {th }}$ May) for the Red-backed Shrike. The surveys were distributed between winter, spring and summer in order to capture a large variety of environmental conditions (e.g. temperature, vegetation) as well as different bird behaviours (wintering, migrating, breeding).

We used a negative binomial mixed model with a logarithm link function to measure species-specific correlations between bird counts and grazer density. The logarithm of the size of grid cells was used as an offset in the linear predictor in order to make counts comparable between grid cells of different sizes (at the edges of the study area, some parts of the grid cells fell outside of the fenced area). We log-transformed grazer densities and therefore replaced values of zero (i.e., zero observations in a grid cell) with half of the minimum non-zero value (Bellego \& Pape 2019). The log-transformed grazer density was used as covariate, and bird species was included as a random factor. Both random intercepts and random slopes were used to model species-specific correlations between bird and grazer density.

We fitted the model using Bayesian methods as implemented in Stan (Stan Development Team 2014) via the function brm from the package brms (Bürkner 2017) in R 3.6.1 (R Core Team 2016). The default flat prior distributions over the reals were used for the average correlation between bird and grazer density. Half-student $\mathrm{t}(3,0,10)$ was used for the variance parameters, and Gamma $(0.01,0.01)$ was used as prior distribution for the shape parameter of the negative binomial distribution.

Peer) reviewing PDF | (2020:09:53031:1:1:NEW 24 Nov 2020) 
174

175

176

177

178

179

180

181

182

183

184

185

186

187

188

189

190

191

192

193

194

195

196

197

198

199

200

201

202

203

204

205

206

207

208

209

210

211

212

213

We assessed model fit by residual analyses and posterior predictive model checking. From the residuals we calculated a semi-variogram to check for spatial correlation, and we calculated the autocorrelations to check for temporal correlation. The semi-variance ranged between 2.5 and 3.5 over the distances 0 to $200 \mathrm{~m}$ and it did not increase with distance. Temporal autocorrelations measured within species and within the $50 \times 50 \mathrm{~m}$ grid cell ranged from -0.002 to 0.004 for the lag of 1 to 10 weeks, and thus we judged these temporal correlations to be small enough to be ignored. We further simulated 2000 different virtual replicated data sets from the model (posterior predictive distribution) and compared the proportion of zero values as well as the variance between the replicated and the real data to check for zero-inflation and overdispersion. The proportion of zero values in the replicated data ranged from 0.97 to 0.98 ( 1 and $99 \%$ quantiles), which included the proportion of zero values in the data (0.98). Also, the standard deviation of the data (1.89) fell within the range of standard deviations of the replicated data from the model ( 0.80 to 8.21 ). Therefore, we concluded that the model described the variance and the proportion of counts of zero of our data well and did not suffer from apparent spatial and temporal correlation.

We used 2000 simulated random values from the joint posterior distribution of the model parameters to describe parameter estimates and their uncertainty. We used the median of the marginal posterior distribution as point estimate and the $2.5 \%$ and $97.5 \%$ quantiles as lower and upper limits of the 95\% Bayesian compatibility intervals (Amrhein et al. 2019a, b).

Code and data are available on an online repository: https://osf.io/g8a6t/?view_only=86a5e3a5f3b54d7aa7681519e4b7df39.

Declaration of analysis and reporting decisions

This is an exploratory study (Amrhein et al. 2017) describing observations of birds and positions of grazers in our study site. Before starting data collection, we did not know which bird species would have sufficient sample sizes for analysis; we selected the eight most suitable study species after looking at the data. In the revision of the paper, as suggested by the referees, we added an analysis on species-specific correlations of horse versus cattle densities with bird count density that we did early in our study but had not reported in the first version of the paper, and we added two new analyses on the correlations between overall songbird density and grazer density and overall songbird species richness and grazer density.

\section{Results}

In total, we observed 2125 individuals from 64 bird species, among them 1620 individuals from 34 songbird species (order Passeriformes; Table 1). The eight most common species that had sufficient sample sizes for statistical analysis ( $>20$ counts) and were clearly connected to the grazed area of our study site all belonged to the songbirds (Table 1). From those eight species, we made a total of 1424 observations. The only species that certainly bred on the grazed 
214 area were the Skylark and the Red-Backed Shrike (these birds were observed showing territorial 215 behaviour such as songflights, or breeding behaviour such as feeding chicks); the White Wagtail 216 may have bred in the study area as well (the habitat was suitable but we did not observe signs of 217 breeding). The Great Tit, Common Starling and Common Blackbird bred in the bushes and 218 patches of forest in and around the fenced area. Barn Swallows were observed foraging in flight 219 and Pipits mainly in flocks on the ground.

220

221

222

223

224

225

226

227

228

229

230

231

232

233

234

235

236

237

238

239

240

241

242

243

244

245

246

247

248

249

250

251

252

253

Median grazer density (numbers of GPS positions per grid cell for the last 30 days prior to a bird survey) did not change markedly over the course of the study (Fig. 2). Variance in grazer density increased in May, indicating that grazing occurred homogeneously on all cells in winter, while during spring and summer some cells were grazed with a higher intensity whereas others were largely avoided by the grazers.

As a first analysis, we fitted our model on correlations between bird count density and grazer density by using separate predictor variables for the densities of horse and cattle positions (thus correcting each grazer species effect for the other grazer species). The correlation between the densities of horse and cattle positions was $r=0.35$. Figure 3 shows that model predictions for the effects of horse versus cattle densities on bird count densities were rather similar in the eight investigated songbird species; for all further analyses, we thus pooled the data for horse and cattle GPS positions.

Bird species that showed a relatively clear positive correlation with pooled grazer density $(\mathrm{P}(\beta>0)$ is relatively high; Table 2, Fig. 4), given our statistical model, were Starlings and Skylarks. In the Starling, our data are most compatible with slopes between 0.28 and 1.02 and in the Skylark with slopes between -0.18 and 0.63 (Table 2). Species with the clearest negative correlations were Blackbirds and Barn Swallows $(\mathrm{P}(\beta>0)$ is relatively low): the data on the Blackbird are most compatible with slopes between -0.92 and 0.07, and in the Barn Swallow with slopes between -1.33 and 0.29 (Table 2). Apart from the Starling, however, the patterns are quite uncertain, given the wide compatibility intervals (Table 2, Fig. 4).

In an additional analysis, we considered the overall densities of songbirds and of grazers, i.e., the numbers of individuals of all songbirds and of all grazer positions summed per grid cell over the entire study period. Figure 5 shows the positive correlation between overall songbird and grazer density (model prediction: $0.21,95 \%$ Bayesian compatibility interval: $0.04-0.38$ ). Further, the species richness (numbers of species) of songbirds per grid cell was positively correlated with the overall grazer density (Fig. 6; model prediction: 0.12, 95\% Bayesian compatibility interval: $0.01-0.23$ ).

\section{Discussion}

We investigated responses of birds to natural grazing in a newly restored nature conservation area by using GPS collars on individual cattle and horses. We studied grazing pressure on a continuous scale of grazer density, which differs from earlier studies categorizing grazing pressure on entire meadows as, e.g., "high" or "low" (e.g., Batary et al. 2007). Our approach

Peer) reviewing PDF | (2020:09:53031:1:1:NEW 24 Nov 2020) 
254

255

256

257

258

259

260

261

262

263

264

265

266

267

268

269

270

271

272

273

274

275

276

277

278

279

280

281

282

283

284

285

286

287

288

289

290

291

292

takes into account that cattle and horses are known for their heterogenous habitat use (Lamoot et al. 2005) and thus that a possible effect of grazing may vary within a given study site. Further, unlike previous studies that investigated either the breeding or winter season (e.g., Hartel et al. 2014; Leal et al. 2019), we considered bird observations starting from winter through the breeding season, with year-round presence of semi-wild grazers. The resulting correlations therefore not only describe density of breeding birds but average relationships between bird and grazer densities over many different environmental conditions and life-cycle stages of birds.

We found that in the songbirds of our study site, both the overall density of individual birds and the number of species increased with increasing density of grazer positions. Among the eight most commonly observed songbird species, the density of Starling observations showed the clearest positive correlation with density of grazer positions. This was to be expected, given that Starlings usually prefer grazed pastures rather than arable farmlands (Heldbjerg et al. 2017) and often follow grazing herds, profiting from flushed insects (Källander 2004). We also found a relatively clear positive correlation in the Skylark (although also slight negative correlations would be compatible with our data, given our model; Amrhein et al. 2019a, b). Skylarks have been suggested to both benefit from and be impeded by grazing (reviewed by Donald 2010). This is because trampling by large herbivores may destroy nests (Pavel 2004; Popotnik \& Giuliano 2000), while the shortened vegetation height benefits Skylarks in terms of food availability, accessibility, and suitable nesting habitat (Odderskær et al. 1997; Wilson et al. 1997). When we looked at the density of GPS positions of horses and cattle separately, accounting for the presence of the other grazer species, we found that the correlations with bird densities were rather similar.

Our results do not necessarily imply a causal relationship between grazing and density of birds; for example, non-causal correlations between grazers and birds could arise because both prefer the same habitat. In our study site, however, the habitat was completely restored and ecological succession started from bare gravel soil in 2014. Although in the meantime some of the growing saplings were removed manually, horses and cattle contribute to keeping the vegetation short and to re-creating pioneer habitats with bare soil (e.g., at resting areas of the grazers) since autumn 2018. Although the degree of causality is hard to quantify, we think it is probably correct to say that Starlings and Skylarks seem to profit from the presence of horses and cattle by using habitats that are kept open by the grazers.

We observed the clearest negative correlations in Blackbirds and Barn Swallows. Possible explanations may be that Blackbirds are often found next to areas with more dense vegetation that may not be preferred by grazers, while Barn Swallows were often observed flying over the water ponds that naturally had low or zero densities of grazer GPS positions. The uncertainty in the correlations found for Pipits, Red-Backed Shrikes, White Wagtails and Great Tits seems too high to allow interpretation, although the slightly positive correlations in Red-Backed Shrikes and Pipits would fit what we would expect given that those species are often found on or next to areas with bare ground.

Peer) reviewing PDF | (2020:09:53031:1:1:NEW 24 Nov 2020) 
293 It will be interesting to investigate in future studies how the space use of birds and grazers 294 varies depending on season and how this affects the correlations between bird and grazer 295 densities. It would also be interesting to study the influence of vegetation and ecological 296 succession on spatial behaviour of grazers and birds, although here again it would be difficult to 297 disentangle cause and effect. Future research could also investigate how food abundance and 298 availability may affect the space use of birds through the indirect effect of grazing on the 299 vegetation.

300 Similar to our study, Köhler et al. (2016) and Kerekes \& Végvári (2016) found that 301 associations between bird abundance and grazing intensity varies greatly among bird species. 302 Also Neilly \& Schwarzkopf (2019) described that responses of birds to grazing are often 303 complex and will reflect habitat requirements of the individual bird species. Whether a possible 304 effect of natural grazing in a nature reserve is meeting conservation goals thus depends on which 305 species one aims to protect. Among the eight most often observed birds in our study, the two 306 species that are most threatened are the Skylark and the Red-Backed Shrike (according to the 307 IUCN Red List; BirdLife 2018; BirdLifeInternational 2017.). The observed positive correlations 308 with grazer densities in those species are encouraging from a conservational point of view, given 309 that natural grazing with horses and cattle is usually implemented to enhance habitat diversity 310 and to support species of conservation concern.

311

\section{Acknowledgements}

313

314 We thank the team of the Réserve Naturelle Petite Camargue Alsacienne to have made it 315 possible to conduct our research in the nature reserve. Lisa Malm and an anonymous referee 316 gave helpful comments on the first version of the paper. 


\section{References}

318

319

320

321

322

323

324

325

326

327

328

329

330

331

332

333

334

335

336

337

338

339

340

341

342

343

344

345

346

347

348

349

350

351

352

353

354

355

356

357

358

Amrhein V, Korner-Nievergelt $F$, and Roth T. 2017. The earth is flat ( $p>0.05)$ : significance thresholds and the crisis of unreplicable research. PeerJ 5:40. 10.7717/peerj.3544

Amrhein V, Greenland S, and McShane B. 2019a. Retire statistical significance. Nature 567:305307. 10.1038/d41586-019-00857-9

Amrhein V, Trafimow D, and Greenland S. 2019b. Inferential statistics as descriptive statistics: there is no replication crisis if we don't expect replication. The American Statistician 73:262-270. 10.1080/00031305.2019.1543137

Baldi A, Batary P, and Erdos S. 2005. Effects of grazing intensity on bird assemblages and populations of Hungarian grasslands. Agriculture, Ecosystems \& Environment 108:251263. 10.1016/j.agee.2005.02.006

Batary P, Baldi A, and Erdos S. 2007. Grassland versus non-grassland bird abundance and diversity in managed grasslands: local, landscape and regional scale effects. Biodiversity and Conservation 16:871-881. 10.1007/s10531-006-9135-5

Bellego C, and Pape L-D. 2019. Dealing with Logs and Zeros in Regression Models. Political Methods: Quantitative Methods eJournal (2019): n. pag.

BirdLife. 2018. Alauda arvensis. The IUCN Red List of Threatened Species 2018:

e.T102998555A132039889. Available at https://dx.doi.org/10.2305/IUCN.UK.20182.RLTS.T102998555A132039889.en. (accessed 31 July 2020).

BirdLife International. 2017. Lanius collurio (amended version of 2016 assessment). The IUCN Red List of Threatened Species 2017: e.T22705001A110988087. Available at https://dx.doi.org/10.2305/IUCN.UK.2017-1.RLTS.T22705001A110988087.en. (accessed 31 July 2020).

Buckland ST, Anderson DR, Burnham KP, Laake JL, Borchers DL, and Thomas L. 2001. Introduction to distance sampling: estimating abundance of biological populations. Oxford University Press.

Bürkner P-C. 2017. brms: An R package for Bayesian multilevel models using Stan. Journal of statistical software 80:1-28.

Collins GH, Petersen SL, Carr CA, and Pielstick L. 2014. Testing VHF/GPS collar design and safety in the study of free-roaming horses. Plos One 9:e103189.

Dawson D, and Bull P. 1975. Counting birds in New Zealand forests. Notornis 22:101-109.

Dawson DG. 1981. Counting birds for a relative measure (index) of density. Studies in avian biology 6:12-16.

Di Orio AP, Callas R, and Schaefer RJ. 2003. Performance of two GPS telemetry collars under different habitat conditions. Wildlife Society Bulletin 31:372-379.

Donald P. 2010. The skylark. Bloomsbury Publishing.

Dross C, Princé K, Jiguet F, and Tichit M. 2018. Contrasting bird communities along production gradients of crops and livestock in French farmlands. Agriculture, Ecosystems \& Environment 253:55-61.

Dussault C, Courtois R, Ouellet J-P, and Huot J. 2001. Influence of satellite geometry and differential correction on GPS location accuracy. Wildlife Society Bulletin 29:171-179.

Peer) reviewing PDF | (2020:09:53031:1:1:NEW 24 Nov 2020) 
359

360

361

362

363

364

365

366

367

368

369

370

371

372

373

374

375

376

377

378

379

380

381

382

383

384

385

386

387

388

389

390

391

392

393

394

395

396

397

398

399

400

401
Gander A, Rockmann A, Strehler C, and Güsewell S. 2003. Habitat use by Scottish Highland cattle in a lakeshore wetland. Bulletin of the Geobotanical Institute ETH 69:3-16.

Ganskopp DC, and Johnson DD. 2007. GPS error in studies addressing animal movements and activities. Rangeland Ecology \& Management 60:350-358.

Gregory RD, Gibbons DW, and Donald PF. 2004. Bird census and survey techniques. In Bird ecology and conservation, pages 17-56. Oxford University Press.

Hartel T, Hanspach J, Abson DJ, Mathe O, Moga Cl, and Fischer J. 2014. Bird communities in traditional wood-pastures with changing management in Eastern Europe. Basic and Applied Ecology 15:385-395.

Heldbjerg H, Fox AD, Thellesen PV, Dalby L, and Sunde P. 2017. Common Starlings (Sturnus vulgaris) increasingly select for grazed areas with increasing distance-to-nest. Plos One 12:e0182504. 10.1371/journal.pone.0182504

Henning K, Lorenz A, von Oheimb G, Hardtle W, and Tischew S. 2017. Year-round cattle and horse grazing supports the restoration of abandoned, dry sandy grassland and heathland communities by supressing Calamagrostis epigejos and enhancing species richness. Journal for Nature Conservation 40:120-130. 10.1016/j.jnc.2017.10.009

Hurn J. 1993. Differential GPS explained: an exposé of the surprisingly simple principles behind today's most advanced positioning technology. Sunnyvale, CA: Trimble Navigation.

Källander H. 2004. Starlings Sturnus vulgaris and cattle-a widespread feeding association. Ornis svecica 14:11-20.

Kerekes V, and Végvári Z. 2016. Effects of wilderness grazing on ground-breeding birds in Pannonian grasslands. Community Ecology 17.2: 149-155.

King SR, and Gurnell J. 2005. Habitat use and spatial dynamics of takhi introduced to Hustai National Park, Mongolia. Biological Conservation 124:277-290.

Köhler M, Hiller G, and Tischew S. 2016. Year-round horse grazing supports typical vascular plant species, orchids and rare bird communities in a dry calcareous grassland. Agriculture, Ecosystems \& Environment 234:48-57. 10.1016/j.agee.2016.03.020

Laiolo P. 2005. Spatial and seasonal patterns of bird communities in Italian agroecosystems. Conservation Biology 19:1547-1556.

Lamoot I, Meert C, and Hoffmann M. 2005. Habitat use of ponies and cattle foraging together in a coastal dune area. Biological Conservation 122:523-536.

Leal Al, Acácio M, Meyer CF, Rainho A, and Palmeirim JM. 2019. Grazing improves habitat suitability for many ground foraging birds in Mediterranean wooded grasslands. Agriculture, Ecosystems \& Environment 270:1-8.

Linnell JD, Kaczensky P, Wotschikowsky U, Lescureux N, and Boitani L. 2015. Framing the relationship between people and nature in the context of European conservation. Conservation Biology 29:978-985.

Loucougaray G, Bonis A, and Bouzille JB. 2004. Effects of grazing by horses and/or cattle on the diversity of coastal grasslands in western France. Biological Conservation 116:59-71. 10.1016/s0006-3207(03)00177-0

Milchunas D, Sala O, and Lauenroth WK. 1988. A generalized model of the effects of grazing by large herbivores on grassland community structure. The American Naturalist 132:87106.

Peer] reviewing PDF | (2020:09:53031:1:1:NEW 24 Nov 2020) 
402

403

404

405

406

407

408

409

410

411

412

413

414

415

416

417

418

419

420

421

422

423

424

425

426

427

428

429

430

431

432

433

434

435

436

437

438

439

440

441

442

443

444

445

Moen R, Pastor J, Cohen Y, and Schwartz CC. 1996. Effects of moose movement and habitat use on GPS collar performance. The Journal of Wildlife Management 60:659-668.

Neilly H, and Schwarzkopf L. 2019. The impact of cattle grazing regimes on tropical savanna bird assemblages. Austral Ecology 44:187-198.

Nikolov SC. 2010. Effects of land abandonment and changing habitat structure on avian assemblages in upland pastures of Bulgaria. Bird Conservation International 20:200-213.

Odderskær P, Prang A, Poulsen JG, Andersen PN, and Elmegaard N. 1997. Skylark (Alauda arvensis) utilisation of micro-habitats in spring barley fields. Agriculture, Ecosystems \& Environment 62:21-29.

Pavel V. 2004. The impact of grazing animals on nesting success of grassland passerines in farmland and natural habitats: a field experiment. Folia Zoologica 53:171-178.

Popotnik GJ, and Giuliano WM. 2000. Response of birds to grazing of riparian zones. The Journal of Wildlife Management 64:976-982.

RCoreTeam. 2016. A language and environment for statistical computing. Vienna, Austria: $R$ Foundation for Statistical Computing.

Rosenthal G, Schrautzer J, and Eichberg C. 2012. Low-intensity grazing with domestic herbivores: a tool for maintaining and restoring plant diversity in temperate Europe. Tuexenia 32:167-205.

Roth RR. 1976. Spatial heterogeneity and bird species diversity. Ecology 57:773-782.

Sharps E, Smart J, Mason LR, Jones K, Skov MW, Garbutt A, and Hiddink JG. 2017. Nest trampling and ground nesting birds: quantifying temporal and spatial overlap between cattle activity and breeding redshank. Ecology and Evolution 7:6622-6633. 10.1002/ece3.3271

Stan Development Team. 2014. Stan Modeling Language Users Guide and Reference Manual. Version 2.2. ed.

Toepfer S, and Stubbe M. 2001. Territory density of the Skylark (Alauda arvensis) in relation to field vegetation in central Germany. Journal für Ornithologie 142:184-194.

Turner L, Udal M, Larson B, and Shearer S. 2000. Monitoring cattle behavior and pasture use with GPS and GIS. Canadian Journal of Animal Science 80:405-413.

Ungar ED, Henkin Z, Gutman M, Dolev A, Genizi A, and Ganskopp D. 2005. Inference of animal activity from GPS collar data on free-ranging cattle. Rangeland Ecology \& Management 58:256-266.

van Klink R, Nolte S, Mandema FS, Lagendijk DDG, WallisDeVries MF, Bakker JP, Esselink P, and Smit C. 2016. Effects of grazing management on biodiversity across trophic levels-The importance of livestock species and stocking density in salt marshes. Agriculture, Ecosystems \& Environment 235:329-339. 10.1016/j.agee.2016.11.001

VanWieren SE. 1995. The potential role of large herbivores in nature conservation and extensive land use in Europe. Biological Journal of the Linnean Society 56:11-23.

Vera FWM. 2000. Grazing ecology and forest history. CABI publishing.

Vermeulen R. 2015. Natural Grazing. Practices in the rewilding of cattle and horses. Nijmegen: Rewilding Europe.

Wilson JD, Evans J, Browne SJ, and King JR. 1997. Territory distribution and breeding success of skylarks Alauda arvensis on organic and intensive farmland in southern England. Journal of Applied Ecology 34:1462-1478. 10.2307/2405262 


\section{Table 1 (on next page)}

List of all observed birds.

The eight more closely investigated songbird species are in bold. 
1 Table 1. List of all observed birds. The eight more closely investigated songbird species are in 2 bold.

3

4

5

\begin{tabular}{|c|c|c|c|}
\hline Songbirds & $\begin{array}{c}\text { Nr of } \\
\text { individuals }\end{array}$ & Other birds & $\begin{array}{c}\mathrm{Nr} \text { of } \\
\text { individuals }\end{array}$ \\
\hline $\begin{array}{l}\text { Common Starling } \\
\text { Sturnus vulgaris }\end{array}$ & 505 & $\begin{array}{l}\text { Common Swift } \\
\text { Apus apus }\end{array}$ & 123 \\
\hline $\begin{array}{l}\text { Barn Swallow } \\
\text { Hirundo rustica }\end{array}$ & 347 & $\begin{array}{l}\text { Mallard } \\
\text { Anas platyrhynchos }\end{array}$ & 72 \\
\hline $\begin{array}{l}\text { Eurasian Skylark } \\
\text { Alauda arvensis }\end{array}$ & 215 & $\begin{array}{l}\text { Mute Swan } \\
\text { Cygnus olor }\end{array}$ & 70 \\
\hline $\begin{array}{l}\text { Pipits } \\
\text { Anthus sp. }\end{array}$ & 194 & $\begin{array}{l}\text { Tufted Duck } \\
\text { Aythya fuligula }\end{array}$ & 56 \\
\hline $\begin{array}{l}\text { Great Tit } \\
\text { Parus major }\end{array}$ & 68 & $\begin{array}{l}\text { Eurasian Teal } \\
\text { Anas crecca }\end{array}$ & 33 \\
\hline $\begin{array}{l}\text { Common Blackbird } \\
\text { Turdus merula }\end{array}$ & 37 & $\begin{array}{l}\text { Green Sandpiper } \\
\text { Tringa ochropus }\end{array}$ & 31 \\
\hline $\begin{array}{l}\text { Red-backed Shrike } \\
\text { Lanius collurio }\end{array}$ & 32 & $\begin{array}{l}\text { Grey Heron } \\
\text { Ardea cinerea }\end{array}$ & 29 \\
\hline $\begin{array}{l}\text { White Wagtail } \\
\text { Motacilla alba }\end{array}$ & 26 & $\begin{array}{l}\text { Eurasian Coot } \\
\text { Fulica atra }\end{array}$ & 22 \\
\hline $\begin{array}{l}\text { Common House Martin } \\
\text { Delichon urbicum }\end{array}$ & 41 & $\begin{array}{l}\text { Common Kingfisher } \\
\text { Alcedo atthis }\end{array}$ & 6 \\
\hline $\begin{array}{l}\text { Winter Wren } \\
\text { Troglodytes troglodytes }\end{array}$ & 20 & $\begin{array}{l}\text { Red-crested Pochard } \\
\text { Netta rufina }\end{array}$ & 6 \\
\hline $\begin{array}{l}\text { Carrion Crow } \\
\text { Corvus corone }\end{array}$ & 17 & $\begin{array}{l}\text { Ruddy Shelduck } \\
\text { Tadorna ferruginea }\end{array}$ & 6 \\
\hline $\begin{array}{l}\text { Long-tailed Tit } \\
\text { Aegithalos caudatus }\end{array}$ & 15 & $\begin{array}{l}\text { Common Buzzard } \\
\text { Buteo buteo }\end{array}$ & 5 \\
\hline $\begin{array}{l}\text { Reed Bunting } \\
\text { Emberiza schoeniclus }\end{array}$ & 13 & $\begin{array}{l}\text { White Stork } \\
\text { Ciconia ciconia }\end{array}$ & 5 \\
\hline $\begin{array}{l}\text { European Robin } \\
\text { Erithacus rubecula }\end{array}$ & 12 & $\begin{array}{l}\text { Little Grebe } \\
\text { Tachybaptus ruficollis }\end{array}$ & 5 \\
\hline $\begin{array}{l}\text { Blue Tit } \\
\text { Cyanistes caeruleus }\end{array}$ & 9 & $\begin{array}{l}\text { Wood Sandpiper } \\
\text { Tringa glareola }\end{array}$ & 5 \\
\hline $\begin{array}{l}\text { Fieldfare } \\
\text { Turdus pilaris }\end{array}$ & 8 & $\begin{array}{l}\text { Common Redshank } \\
\text { Tringa totanus }\end{array}$ & 5 \\
\hline $\begin{array}{l}\text { Common Raven } \\
\text { Corvus corax }\end{array}$ & 7 & $\begin{array}{l}\text { Little Ringed Plover } \\
\text { Charadrius dubius }\end{array}$ & 4 \\
\hline $\begin{array}{l}\text { Common Chaffinch } \\
\text { Fringilla coelebs }\end{array}$ & 7 & $\begin{array}{l}\text { Black Kite } \\
\text { Milvus migrans }\end{array}$ & 4 \\
\hline $\begin{array}{l}\text { European Greenfinch } \\
\text { Carduelis chloris }\end{array}$ & 6 & $\begin{array}{l}\text { Common Snipe } \\
\text { Gallinago gallinago }\end{array}$ & 3 \\
\hline Common Chiffchaff & 6 & Northern Shoveler & 3 \\
\hline
\end{tabular}




\begin{tabular}{|l|c|l|c|}
\hline Phylloscopus collybita & & Spatula clypeata & \\
\hline $\begin{array}{l}\text { Garden Warbler } \\
\text { Sylvia borin }\end{array}$ & 5 & $\begin{array}{l}\text { Little Egret } \\
\text { Egretta garzetta }\end{array}$ & 2 \\
\hline $\begin{array}{l}\text { Yellowhammer } \\
\text { Emberiza citrinella }\end{array}$ & 4 & $\begin{array}{l}\text { Eurasian Wryneck } \\
\text { Jynx torquilla }\end{array}$ & 2 \\
\hline $\begin{array}{l}\text { Grey Wagtail } \\
\text { Motacilla cinerea }\end{array}$ & 4 & $\begin{array}{l}\text { Ferruginous Duck } \\
\text { Aythya nyroca }\end{array}$ & 1 \\
\hline $\begin{array}{l}\text { Eurasian Blackcap } \\
\text { Sylvia atricapilla }\end{array}$ & 4 & $\begin{array}{l}\text { Middle Spotted Woodpecker } \\
\text { Leiopicus medius }\end{array}$ & 1 \\
\hline $\begin{array}{l}\text { Common Whitethroat } \\
\text { Sylvia communis }\end{array}$ & 4 & $\begin{array}{l}\text { Lesser Spotted Woodpecker } \\
\text { Dryobates minor }\end{array}$ & 1 \\
\hline $\begin{array}{l}\text { Eurasian Siskin } \\
\text { Spinus spinus }\end{array}$ & 3 & $\begin{array}{l}\text { Great Egret } \\
\text { Ardea alba }\end{array}$ & 1 \\
\hline $\begin{array}{l}\text { Eurasian Reed Warbler } \\
\text { Acrocephalus scirpaceus }\end{array}$ & 2 & $\begin{array}{l}\text { Eurasian Hobby } \\
\text { Falco subbuteo }\end{array}$ & 1 \\
\hline $\begin{array}{l}\text { European Goldfinch } \\
\text { Carduelis carduelis }\end{array}$ & 2 & $\begin{array}{l}\text { Ruff } \\
\text { Philomachus pugnax }\end{array}$ & 1 \\
\hline $\begin{array}{l}\text { Western Yellow Wagtail } \\
\text { Motacilla flava }\end{array}$ & 2 & $\begin{array}{l}\text { Northern Lapwing } \\
\text { Vanellus vanellus }\end{array}$ & 1 \\
\hline $\begin{array}{l}\text { Tree Pipit } \\
\text { Anthus trivialis }\end{array}$ & 1 & $\begin{array}{l}\text { Eurasian Sparrowhawk } \\
\text { Accipiter nisus }\end{array}$ & 1 \\
\hline $\begin{array}{l}\text { Eurasian Jay } \\
\text { Garrulus glandarius }\end{array}$ & 1 & & \\
\hline $\begin{array}{l}\text { Savi's warbler } \\
\text { Locustella luscinioides }\end{array}$ & 1 & & \\
\hline $\begin{array}{l}\text { Dunnock } \\
\text { Prunella modularis }\end{array}$ & 1 & & \\
\hline $\begin{array}{l}\text { Whinchat } \\
\text { Saxicola rubetra }\end{array}$ & & & \\
\hline
\end{tabular}

6 


\section{Table 2 (on next page)}

Characteristics of the marginal posterior distribution of the model parameters: medians, 2.5 and $97.5 \%$ quantiles (limits of the $95 \%$ Bayesian compatibility interval) and proportions of posterior mass above zero $(P(b>0))$.

The posterior mass corresponds to the posterior probability of the hypothesis that the parameter value is positive; values close to 1 indicate strong evidence for a positive relationship, values close to zero indicate strong evidence for a negative relationship. 
1 Table 2. Characteristics of the marginal posterior distribution of the model parameters:

2 medians, 2.5 and $97.5 \%$ quantiles (limits of the $95 \%$ compatibility interval) and

3 proportions of posterior mass above zero $(\mathrm{P}(\boldsymbol{\beta}>\mathbf{0}))$.

4 The posterior mass corresponds to the posterior probability of the hypothesis that the parameter

5 value is positive; values close to 1 indicate strong evidence for a positive relationship, values

6 close to zero indicate strong evidence for a negative relationship.

7

8

\begin{tabular}{|l|l|l|l|l|}
\hline Parameter & $\begin{array}{l}\text { Median of } \\
\text { posterior }\end{array}$ & $\mathbf{2 . 5 \%}$ quantile & $\mathbf{9 7 . 5 \%}$ quantile & $\mathbf{P}(\boldsymbol{\beta}>\mathbf{0})$ \\
\hline Intercept & -10.5 & -11.7 & -9.2 & - \\
\hline Grazer density average & 0.02 & -0.44 & 0.48 & 0.53 \\
\hline Grazer density Starling & 0.62 & 0.28 & 1.02 & $>0.99$ \\
\hline Grazer density Skylark & 0.21 & -0.18 & 0.63 & 0.86 \\
\hline Grazer density Red-backed Shrike & 0.13 & -0.35 & 0.67 & 0.71 \\
\hline Grazer density Pipits & 0.12 & -0.60 & 0.86 & 0.65 \\
\hline Grazer density Great Tit & 0.03 & -0.40 & 0.45 & 0.56 \\
\hline Grazer density Wagtail & -0.16 & -0.74 & 0.38 & 0.26 \\
\hline Grazer density Blackbird & -0.38 & -0.92 & 0.07 & 0.06 \\
\hline Grazer density Barn Swallow & -0.48 & -1.33 & 0.29 & 0.12 \\
\hline SD species intercept & 1.47 & 0.86 & 3.13 & - \\
\hline SD species grazer density & 0.51 & 0.21 & 1.22 & - \\
\hline Negative binomial shape & 0.013 & 0.011 & 0.015 & - \\
\hline
\end{tabular}

10 


\section{Figure 1}

Map of the study site.

The ecologically restored area (approximately $100 \mathrm{ha}$ ) on the Rhine island of the nature reserve Petite Camargue Alsacienne in France, and the 32-ha study site (test grazing-area), marked by the white dashed line. 


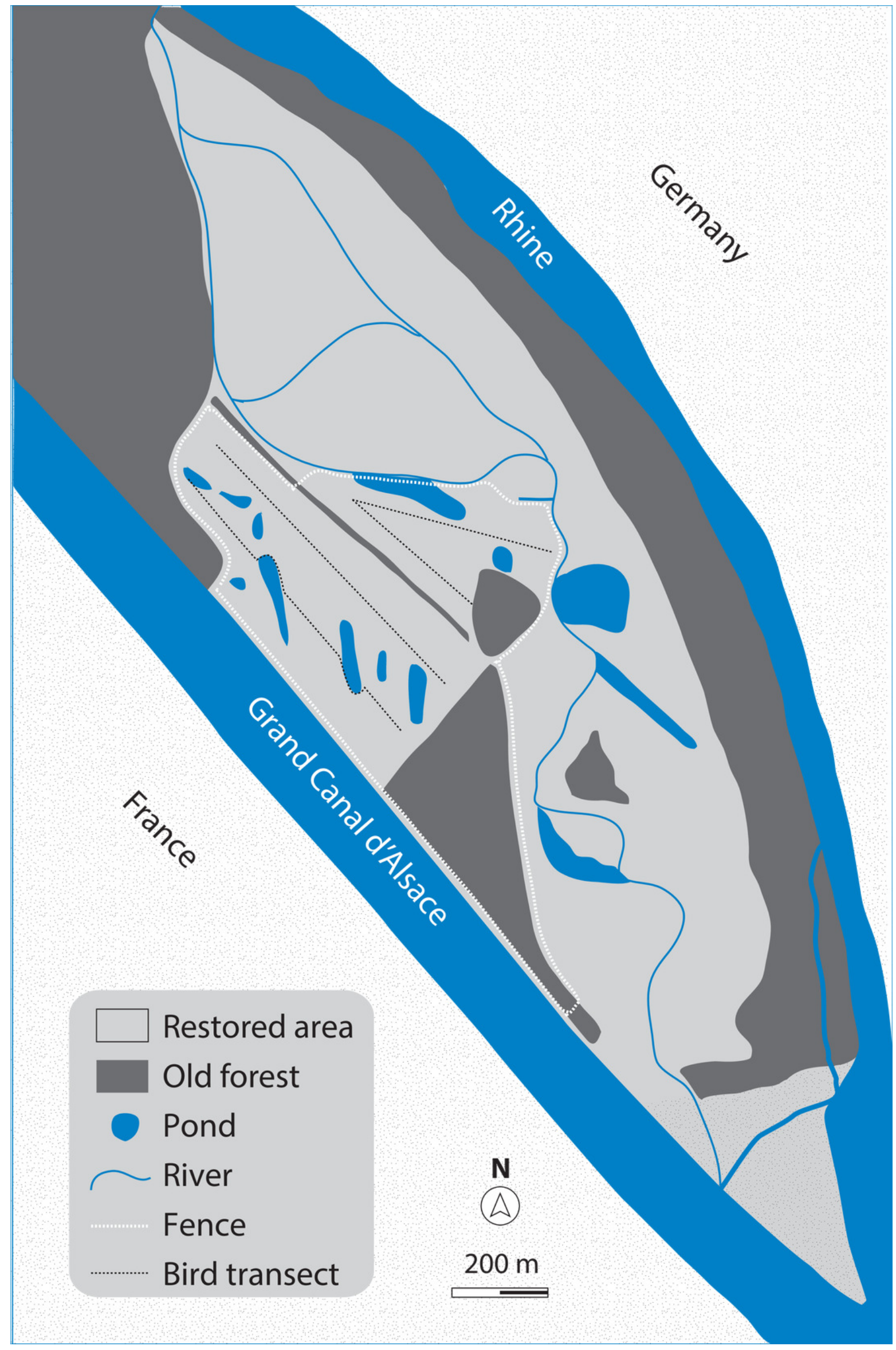


Figure 2

Grazer density during 22 bird surveys in the course of the study period (January to July).

Boxplots show the distribution of grazer densities, given as numbers of pooled GPS positions of horses and cattle per grid cell $(n=113)$ for the last 30 days prior to a bird survey. Day of year corresponds to the dates of bird surveys ( $1=1$ st January). The blue line indicates the standard deviation of grazer densities for each survey.

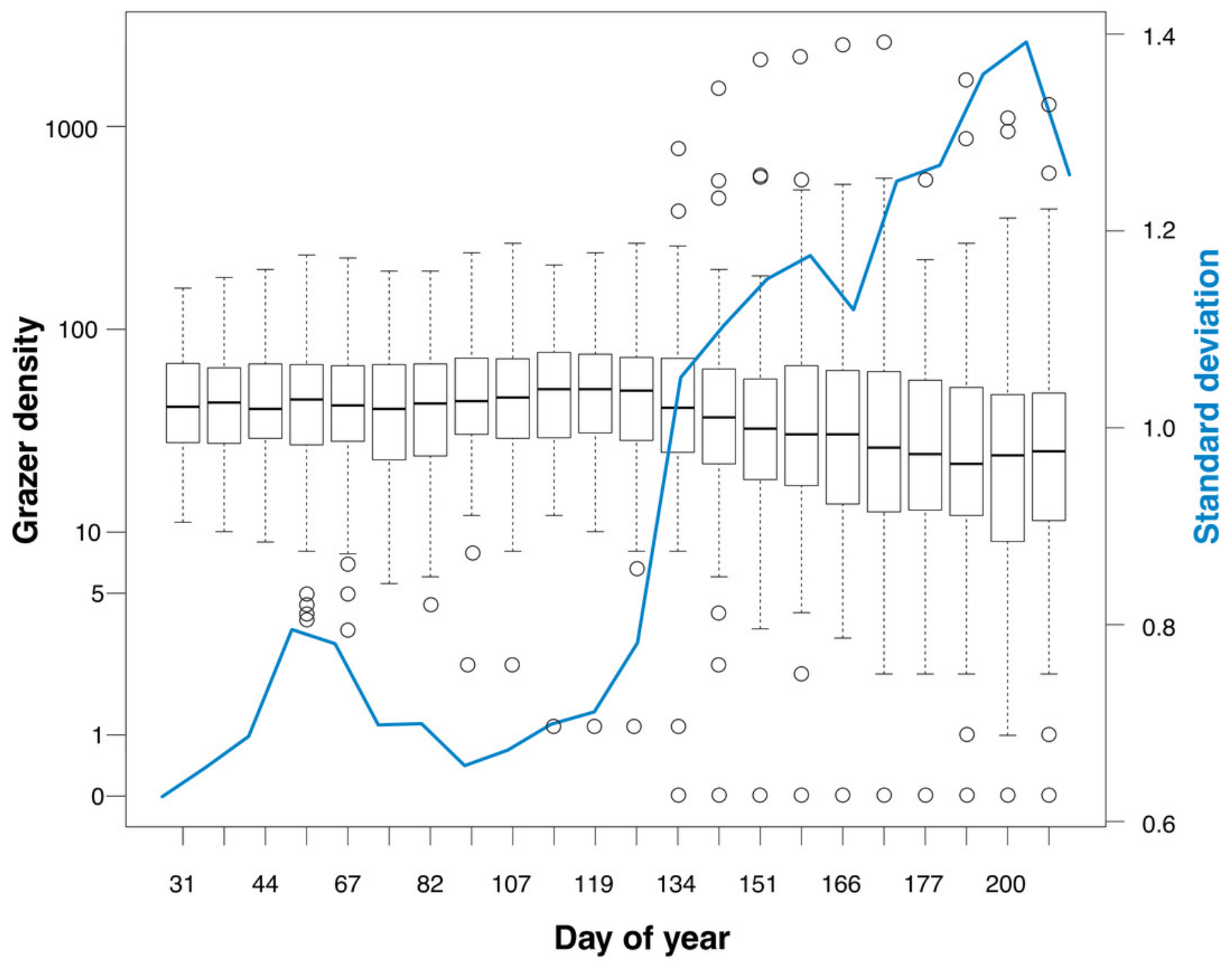


Figure 3

Species-specific correlations of horse and cattle density (numbers of GPS positions per grid cell for the last 30 days prior to a bird survey) with bird count density (numbers of bird counts per survey per grid cell) for the eight most common songbird spe

Given are medians (circles) and 95\% Bayesian compatibility intervals (lines) of model predictions.

- Horses - Cattle

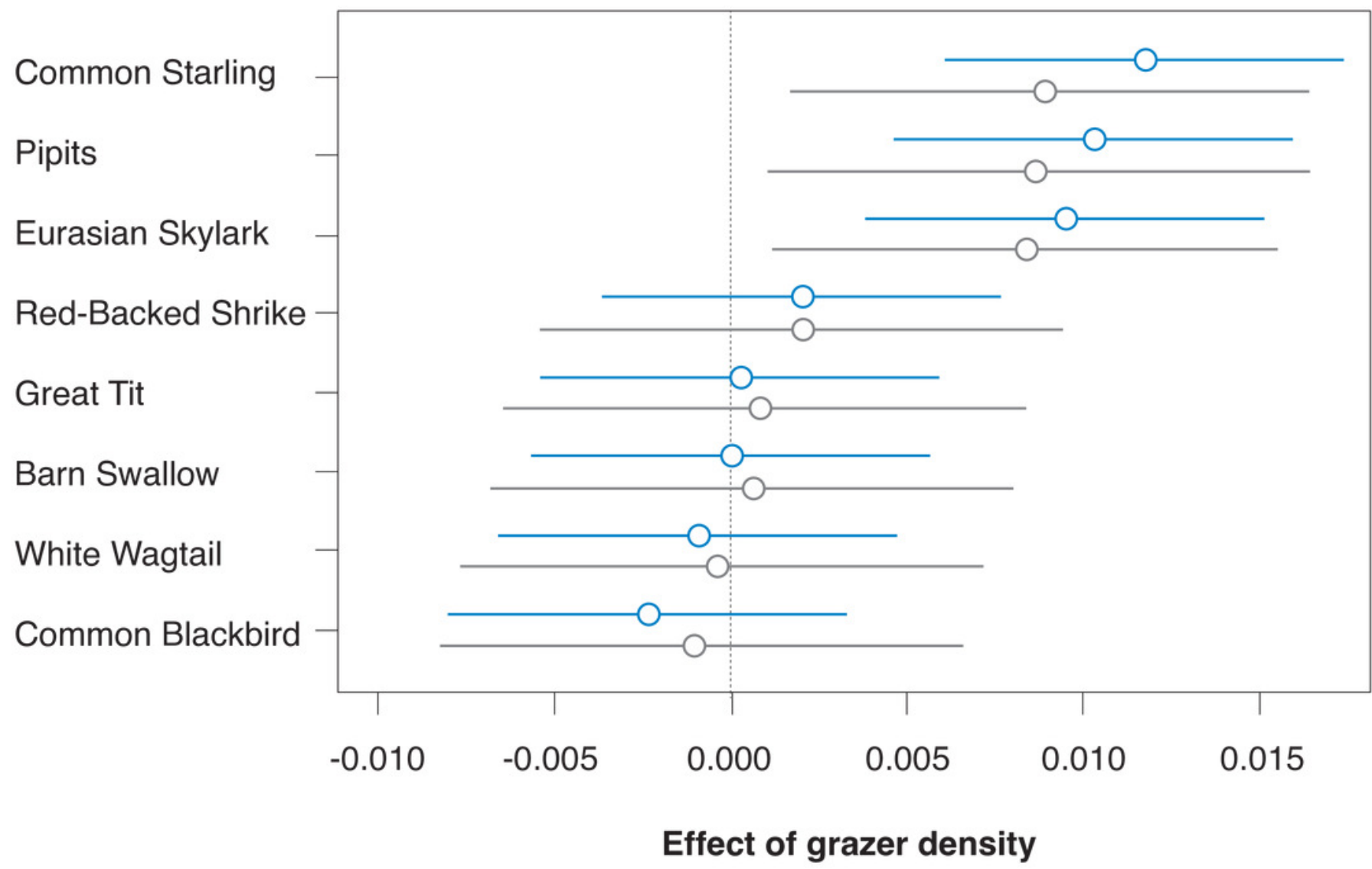




\section{Figure 4}

Correlations between bird count density (numbers of bird counts per survey per grid cell) and grazer density (numbers of pooled GPS positions of horses and cattle per grid cell for the last 30 days prior to a bird survey).

Given are medians (solid lines) and 95\% Bayesian compatibility intervals (dotted lines) of model predictions. Sample sizes ( $n$ ) refer to the total number of birds counted in 113 grid cells during 22 surveys. 


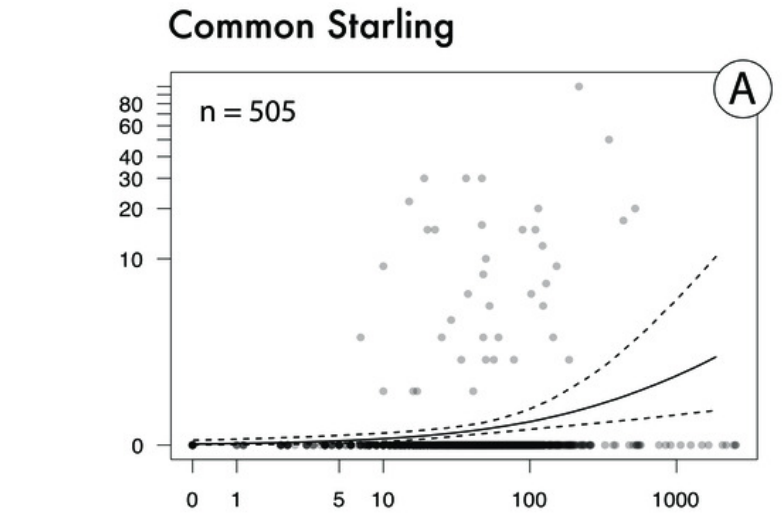

\section{Eurasian Skylark}
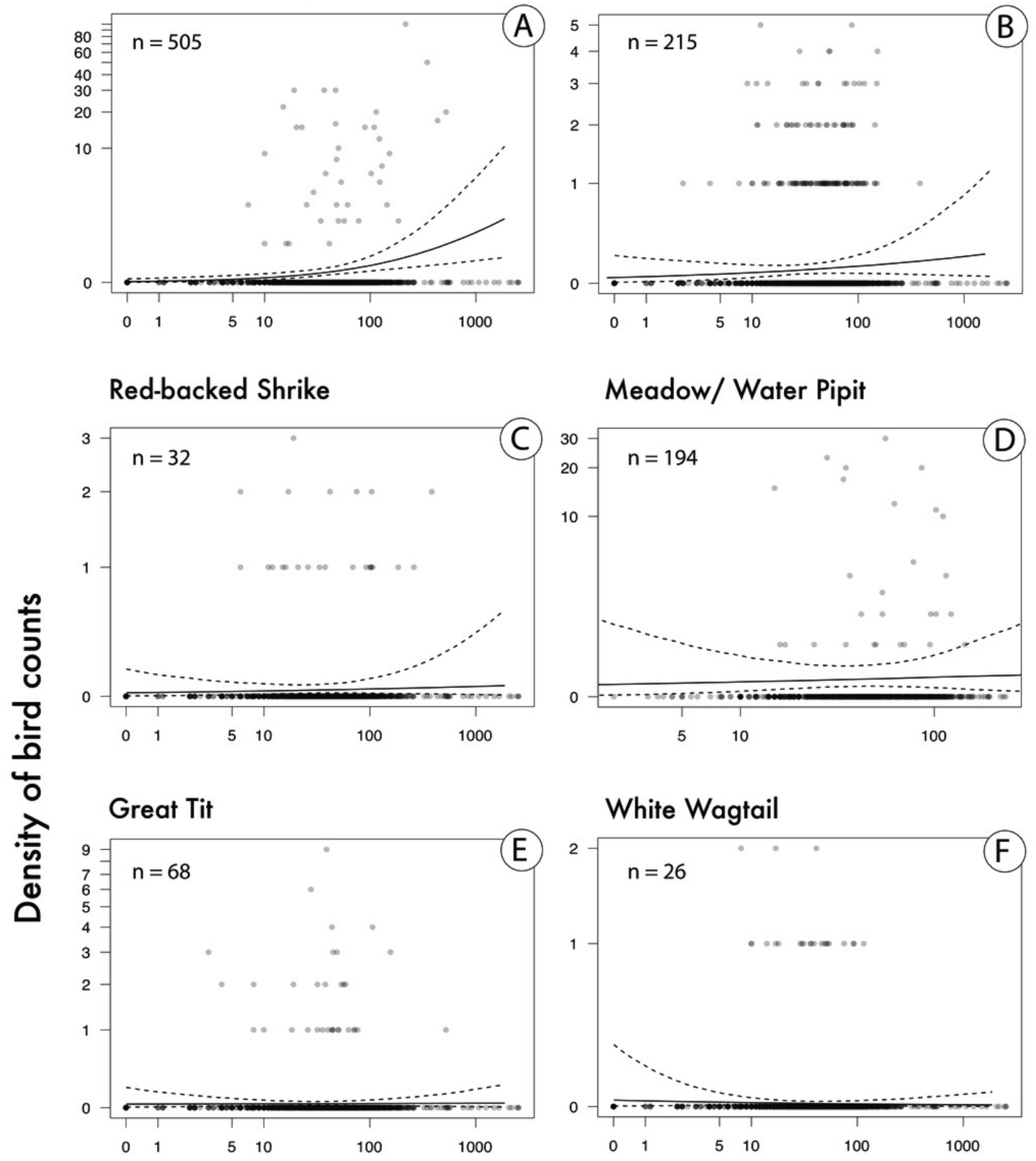

Meadow/ Water Pipit

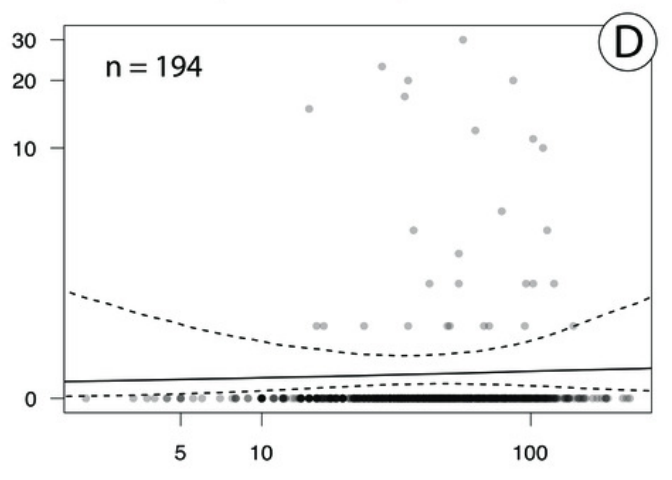

Common Blackbird

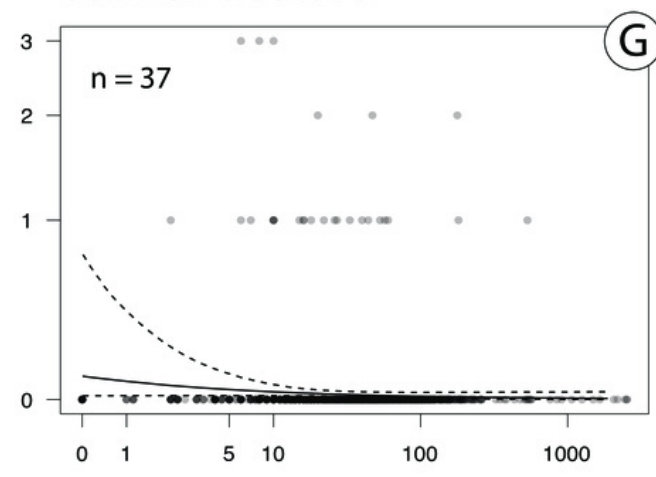

White Wagtail

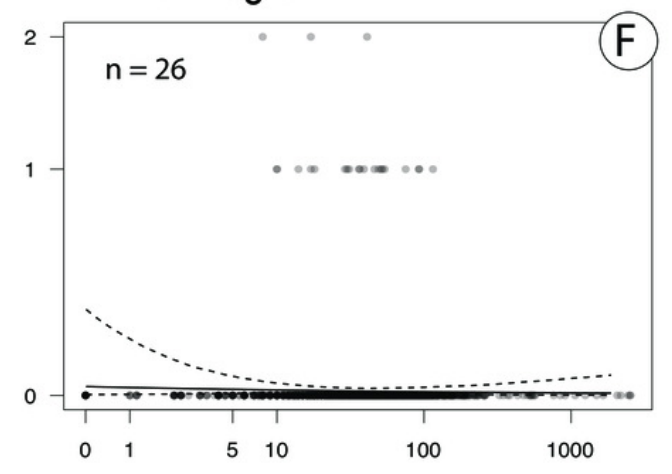

Barn Swallow

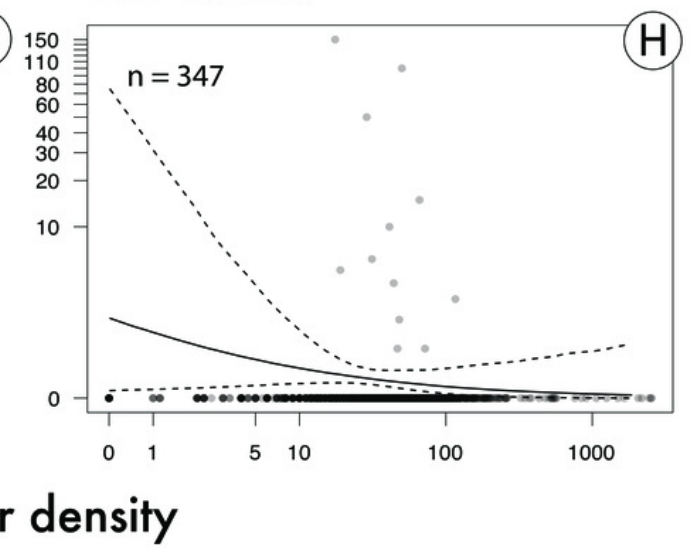


Figure 5

Correlation between overall songbird density (numbers of individuals of all songbird species per survey per grid cell) and grazer density (numbers of pooled GPS positions of horses and cattle per grid cell for the last 30 days prior to a bird survey).

Given are medians (solid line) and 95\% Bayesian compatibility interval (dotted lines) of model predictions.

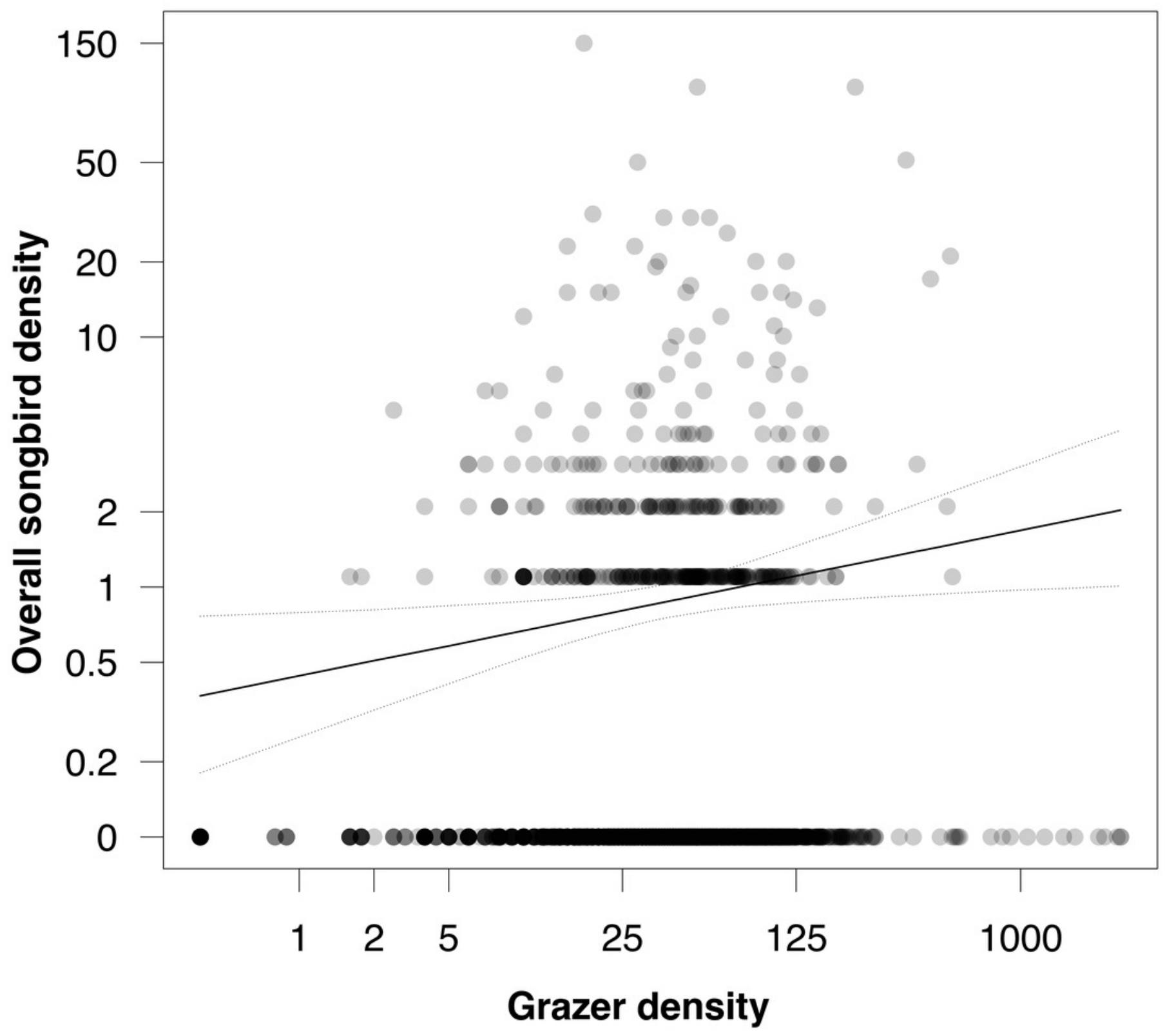


Figure 6

Correlation between overall songbird species richness (numbers of all songbird species per survey per grid cell) and grazer density (numbers of pooled GPS positions of horses and cattle per grid cell for the last 30 days prior to a bird survey).

Given are medians (solid line) and 95\% Bayesian compatibility interval (dotted lines) of model predictions.

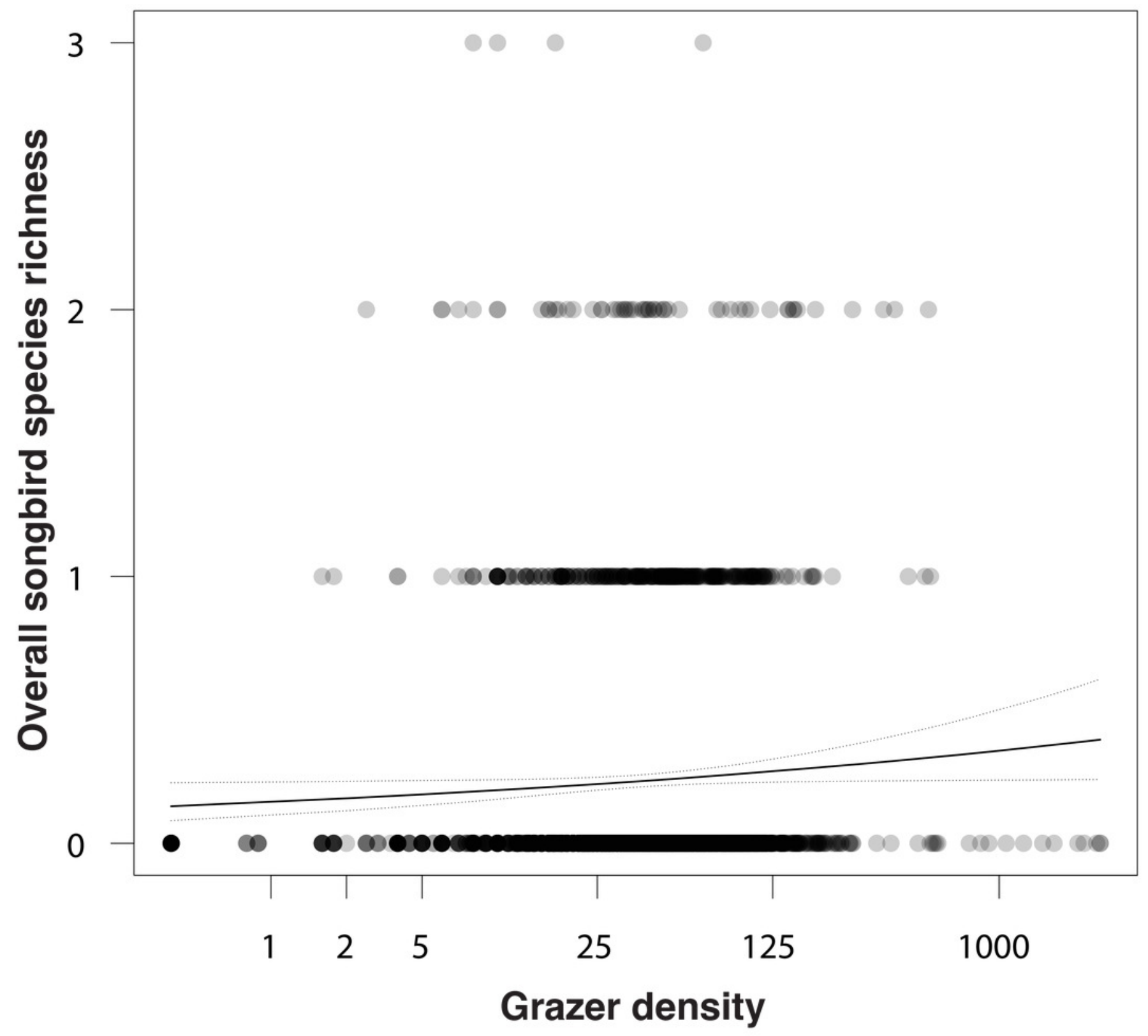

